\title{
$\mathrm{Rh}$ 표현형에 대한 동종면역반응으로 인한 지연성 용혈수혈반응의 2예
}

유동원 ${ }^{1} \cdot$ 이현지 ${ }^{1} \cdot$ 이선민 $^{1} \cdot$ 김인숙 $^{1} \cdot$ 송두열 $^{1} \cdot$ 장철훈 $^{1} \cdot$ 신경화 $^{2} \cdot$ 김형회 $^{2}$

양산부산대학교병원 진단검사의학과 ${ }^{1}$, 부산대학교병원 진단검사의학과 ${ }^{2}$

\section{Delayed Hemolytic Transfusion Reaction with Alloimmunization of Rh Phenotype: A Two-Case Study}

\author{
Dong-Won Yoo ${ }^{1}$, Hyun-Ji Lee ${ }^{1}$, Sun-Min Lee ${ }^{1}$, In-Suk Kim ${ }^{1}$, Duyeal Song ${ }^{1}$, Chulhun L. Chang ${ }^{1}$, \\ Kyung-Hwa Shin', Hyung-Hoi Kim²
}

Department of Laboratory Medicine, Pusan National University Yangsan Hospital ${ }^{1}$, Yangsan, Department of Laboratory Medicine, Pusan National University Hospital ${ }^{2}$, Busan, Korea

Delayed hemolytic transfusion reaction is difficult to prevent using an unexpected antibody test performed prior to transfusion, and unlike acute hemolytic transfusion reaction, it occurs a few days after blood transfusion. Hence, determining the reason for delayed hemolytic transfusion reaction may be a tim-consuming task for clinicians Here, we report our experience of two cases of delayed hemolytic transfusion reaction as a result of the unexpected antibody production to $\mathrm{Rh}$ blood group antigens after transfusion. The first patient with a history of transfusion during admission was identified as having anti-E and anti-C antibodies according to the antibody identification test at the time of re-admission. The second patient who had chronic blood transfusion due to cancer treatment was found to have anti-C antibody. Both patients received transfusion of $\mathrm{Rh}$ antigen-compatible $\mathrm{RBC}$ units only after unexpected antibody development. However, like both cases, patients receiving continuous blood transfusion should be considered for a routine Rh phenotype test. (Korean J Blood Transfus 2017;28:163-169)

Key words: Alloimmunization, Delayed hemolytic transfusion reactions, Rh subgroup, Unexpected antibody

\section{서 론}

수혈은 환자의 생명유지 및 치료에 있어서 중 요한 방법이지만, 타인의 적혈구 항원에 노출됨 으로 인해 생기는 동종면역(alloimmunization)을
막을 수 없다. 그리고 동종면역의 결과 지연성 용 혈수혈반응(Delayed hemolytic transfusion reaction, DHTR)이 발생할 수 있다. 지연성 용혈수혈반응 은 두 단계로 나누어진다[1]. 먼저 동종면역 단계 로 이 때는 용혈반응이 나타나지 않는다. 다음 단

Received on July 12, 2017. Revised on August 10, 2017. Accepted on August 10, 2017

Correspondence to: Hyun-Ji Lee

Department of Laboratory Medicine, Pusan National University Yangsan Hospital, 20 Geumo-ro, Mulgeum-eup, Yangsan 50612, Korea Tel: 82-55-360-1875, Fax: 82-55-360-1880, E-mail: hilhj1120@gmail.com, ORCID: http://orcid.org/0000-0002-9021-5632

() This is an Open Access article distributed under the terms of the Creative Commons Attribution Non-Commercial License (http://creativecommons.org/licenses/by-nc/4.0) which permits unrestricted non-commercial use, distribution, and reproduction in any medium, provided the original work is properly cited.

Copyright (C) 2017 The Korean Society of Blood Transfusion 
계로, 동종면역 이후 수혈 시 동일 항원에 노출되 면 기억반응으로 인하여 비예기 항체가 급속히 증가하여 수혈된 적혈구의 용혈을 일으키게 한다 [2]. 지연성 용혈수혈반응은 수혈 후 3 13일 정 도에 설명되지 않은 비예기 항체가 생성되어 용 혈반응이 발생하게 되며, 환자가 사망에 이를 수 도 있다. 이러한 이상반응을 초래하는 비예기 항 체로는 Rh항체 및 kidd, Duffy, kell 항체 등이 현 재 알려져 있다[3].

지연성 용혈수혈반응은 수혈 시행 후 환자에 게 나타나는 비정상 소견이 수혈로 인한 것이라 고 의심하지 않으면, 진단을 빠르게 할 수 없다. 이로 인해 환자가 불필요한 검사를 시행하기도 하고, 빠른 처치를 하지 못 해 생명이 위험 할 수 도 있다. 본 저자들은 수혈로 인한 동종면역의 결 과로 지연성 용혈수혈반응이 발생한 증례 2 례를 보고하는 바이다.

\section{증 례}

\section{Case1}

64세 여성 환자가 췌장의 신경내분비암종으로 진단받고 항암치료를 권유 받았지만, 이를 거부 하여 퇴원하였다. 이후 타 병원에서 담관 스텐트 삽입술을 2 회 시행하였던 것 외에는 특별한 치료 를 받지 않았다. 환자는 내원 1 주일 전부터 혈뇨 가 보여 응급실 통해 소화기내과 입원하였으며, 응급실 내원 당시 혈액형은 $\mathrm{AB}$ 형, 비예기항체 선 별검사(Diacell I, II, Dia; DiaMed, Murten, Switzerland)에서는 음성소견 보였다. 환자는 응 급실 내원 당시 적혈구 제제 두 단위를 수혈 받았 고 입원 후에도 추가적으로 4 단위를 수혈 받아 총 6 단위 수혈을 받았다. 입원 19일째, 항체 선별 검사에서 처음으로 양성결과를 보였다. 항체 동
정검사(DiaMed-ID system, Murten, Switzerland)의 효소단계에서 환자혈청과 자가적혈구와의 응집 반응을 보이고 11 개의 항체동정용적혈구에서는 모두 $2+$ 이상의 혼합시야소견을 보였다. 항글로 불린단계에서도 자가적혈구와의 응집반응을 보 이고, 5 개의 항체동정용적혈구에서 $1+$ 이상 양 성소견을 보였다. 자가적혈구와의 응집반응 때문 에 ZZAP 시약을 사용한 뒤 다시 시행한 비예기 항체 동정검사에서는 자가적혈구와는 반응하지 않았으며, 11 개의 항체동정용적혈구중에 효소처 리 동정용세포에서만 양성결과 보였고 항체는 anti-C로 동정되었다. 환자의 혈뇨는 지연성 용혈 수혈 이상반응의 결과라고 생각하여 추가 검사를 시행하였다. $\mathrm{Hb} 6.9 \mathrm{~g} / \mathrm{dL}, \mathrm{LDH} 1370 \mathrm{IU} / \mathrm{L}$, 직접빌리 루빈 $3.20 \mathrm{mg} / \mathrm{dL}$, 직접항글로불린검사에서 $2+$ 양 성이었고 haptoglobin $114 \mathrm{mg} / \mathrm{dL}(30 \sim 200 \mathrm{mg} / \mathrm{dL})$, 혈장혈색소는 $23.61 \mathrm{mg} / \mathrm{dL}(0 \sim 11 \mathrm{mg} / \mathrm{dL})$ 이었다. 수혈 이후 항체선별검사에서 양성이 나온 일자에 시행한 환자의 $\mathrm{Rh}$ 아형 검사결과는 $\mathrm{CcDEe}$ 였다. 환자에게 수혈된 혈액제제의 $\mathrm{Rh}$ 표현형과 항체 동정검사 결과는 각각 Table 1, 2에 표시하였다.

위의 환자는 $\mathrm{Rh}$ 표현형검사에서 $\mathrm{CcDEe}$ 가 나 왔었지만, $\mathrm{E}$ 항원에 대해서만 $4+$ 가 나왔을 뿐 $\mathrm{C}$, $\mathrm{c}$, e에서 모두 $4+$ 미만의 항원 양성 혈구와 음성 혈구가 공존하는 결과(double cell population)를 보였다. 환자는 당시 $\mathrm{Hb} 6.9 \mathrm{~g} / \mathrm{dL}$ 로 즉시 수혈을 필요로 하는 적응증에 해당 되었다. 혈액원에서 는 19 개의 혈액제제에 대한 겔카드 교차시험을 통해서 2 개의 $\mathrm{pRBC}$ 적합 혈액제제를 찾아서 출 고 하였다. 혈액은행에서 검사를 진행하는데 소 요된 시간은 약 2 시간이며, 출고 전에 4 개의 길카 드를 사용하여 검사를 완료하였다. 환자는 췌장 암으로 이미 간 및 다른 장기로 전이가 있었으며 혈변도 관찰되어 지속적으로 수혈이 예상되었다. $\mathrm{Rh}$ phenotype이 불확실한 경우 항체가 동정되더 
Table 1. Rh subtypes of packed red blood cells transfused $\mathrm{pRBC}$ to patients

\begin{tabular}{|c|c|c|c|c|c|c|}
\hline \multirow{2}{*}{ Patient } & \multirow{2}{*}{ pRBC No. } & \multirow{2}{*}{ Transfusion Date } & \multicolumn{4}{|c|}{$\mathrm{Rh}$ subgroup } \\
\hline & & & $\mathrm{C}$ & $\mathrm{c}$ & $\mathrm{E}$ & $\mathrm{e}$ \\
\hline \multirow{6}{*}{$\begin{array}{l}\text { Case } 1 \\
\text { (CcDEe in Adm 19th) }\end{array}$} & 1 & Adm 1 & + & - & - & + \\
\hline & 2 & Adm 1 & + & + & + & + \\
\hline & 3 & Adm 4 & + & - & - & + \\
\hline & 4 & Adm 10 & + & - & - & + \\
\hline & 5 & Adm 15 & + & + & + & + \\
\hline & 6 & Adm 15 & + & - & - & + \\
\hline \multirow{5}{*}{$\begin{array}{l}\text { Case } 2 \\
\text { (CDe in POD 22nd) }\end{array}$} & 1 & POD 0 & + & + & + & + \\
\hline & 2 & POD 0 & + & - & - & + \\
\hline & 3 & POD 0 & - & + & + & + \\
\hline & 4 & POD 0 & + & - & - & + \\
\hline & 5 & POD 3 & - & + & + & - \\
\hline
\end{tabular}

Abbreviations: Adm, postadmission day; POD, postoperativeday.

라도 겔카드 교차시험을 통해서 적합 혈액제제를 찾을 수 밖에 없었으므로 혈액원에서 검사상 소 요되는 시간은 계속해서 증가하였다.

\section{Case2}

75세 여자 환자가 상행대동맥 동맥류로 흉부 외과에서 수술을 받고 수술 15 일 뒤에 퇴원하였 다. 퇴원 후 6일째 외래 검사에서 $\mathrm{Hb} 8.5 \mathrm{~g} / \mathrm{dL}$, $\mathrm{LDH} 924 \mathrm{IU} / \mathrm{L}$, 총빌리루빈 $2.06 \mathrm{mg} / \mathrm{dL}$, 직접빌리 루빈 $1.2 \mathrm{mg} / \mathrm{dL}$ 이 결과로 나왔다. 수술 중 적혈구 제제 5 단위를 수혈 받았으며 수술 후 1 단위를 추 가로 수혈 받았다. 검사결과를 고려했을 때, 지연 성 용혈수혈 이상반응이 의심되어 추가 검사를 시행하였으며, 직접 항글로불린 검사에서 음성이 었고 간접 항글로불린 검사에서 $2+$ 양성이었다. 수혈 전 환자의 비예기항체 선별검사에서는 음성 이었지만, 첫 수혈 후 22 일이 지난 뒤에 채취한 검체에서 시행한 항체선별검사(Diacell I, II, Dia; DiaMed, Murten, Switzerland)에서는 양성결과를 보였으며, 비예기항체 동정검사(DiaMed-ID sys- tem, Murten, Switzerland)에서 Anti-E, c가 발견되 었다. 환자의 $\mathrm{Rh}$ 표현형은 $\mathrm{CDe}$ 로 확인되었다. 환 자에게 수혈되었던, 적혈구제제 6 단위에 대하여 $\mathrm{Rh}$ 표현형검사를 시행한 결과 수술 당시 수혈되 었던 2개 적혈구제제와 이후 추가 수혈된 1 개의 적혈구제제에서 $\mathrm{E}$ 와 $\mathrm{c}$ 의 $\mathrm{Rh}$ 항원이 확인되었다. 따라서 환자에게 추가 수혈의 필요가 있을 경우 $\mathrm{E}$ 와 $\mathrm{c}$ 항원 음성제제를 출고하도록 지시하였다. 환자에게 수혈된 혈액제제의 $\mathrm{Rh}$ 표현형과 항체 동정검사 결과를 각각 Table 1,3 에 표시하였다.

\section{고 찰}

과거에는 수혈부작용 중에 잘못된 $\mathrm{ABO}$ 및 $\mathrm{RhD}$ 형 수혈로 인한 급성 용혈수혈반응이 주로 발생하였지만, 최근 검사기법의 발달과 환자확인 등 행정 부분에서의 오류발생이 감소하여 이상반 응이 꾸준히 감소하고 있다. 하지만 대조적으로 지연성 용혈수혈반응은 현재까지 발생에 대한 예 상이 어려우며 통계적으로 지연성 용혈수혈반응 


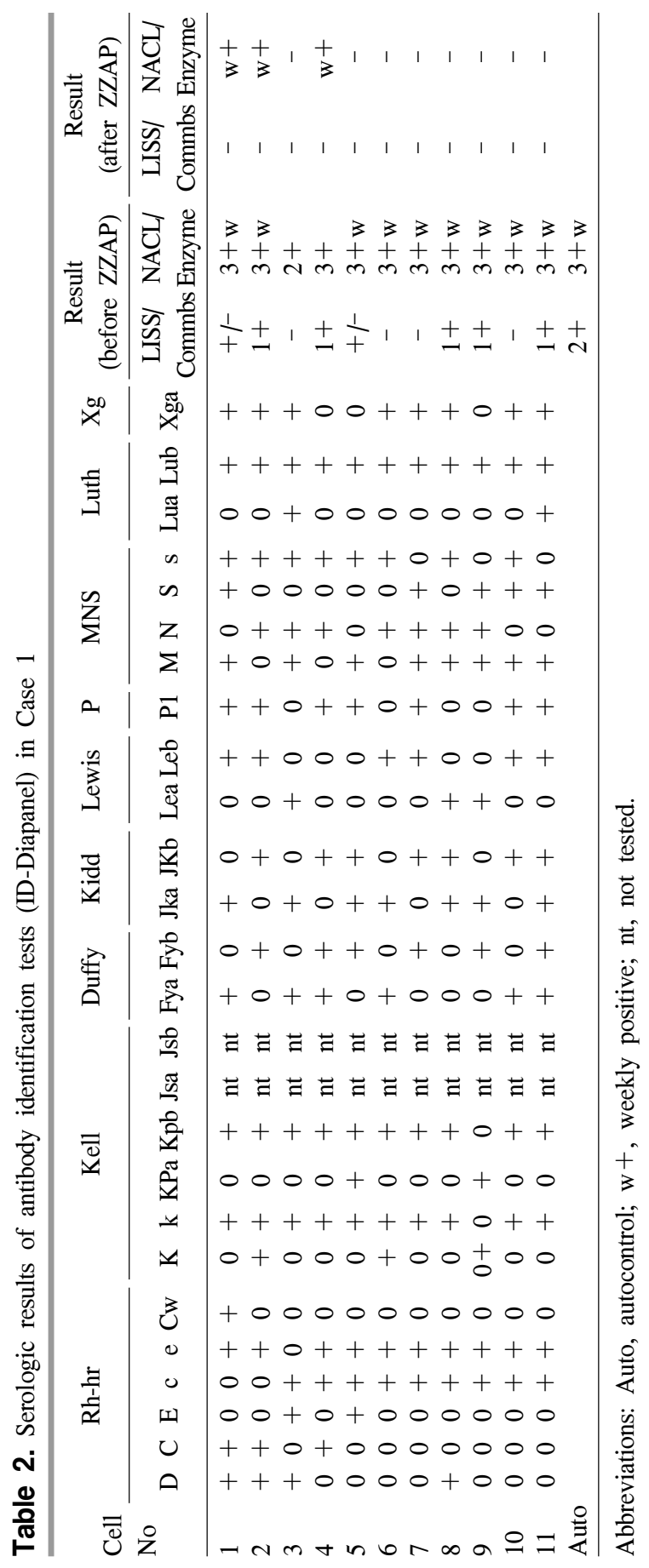

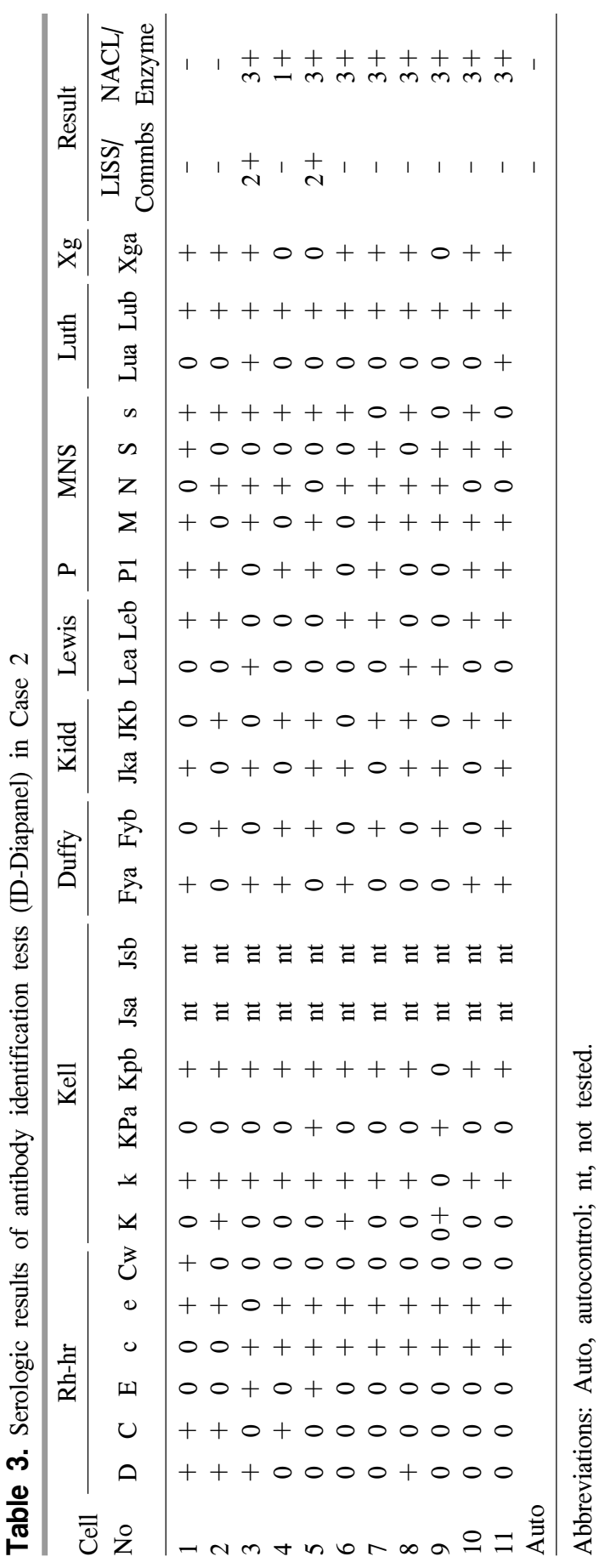


의 발생이 증가하고 있으므로 그 중요성 역시 증 가하고 있다. 지연성 용혈수혈반응은 수혈 후 24 시간부터 28 일 사이에 직접항글로불린 검사가 양 성으로 나타나면서 용출된 항체가 수혈된 적혈구 에 존재하는 항원과 반응하는 항체임을 확인하거 나 환자 혈액의 항체선별 및 동정검사에서 새로 운 항체를 발견하는 것으로 알 수 있다[1]. 이러한 이상반응은 임신이나 수혈을 통해 이미 어떤 적 혈구 항원에 노출되어 감작된 사람에게 나타나게 된다. 또한 감작된 사람이 수혈로 인해 같은 적혈 구 항원에 재노출되면 기왕반응을 통해 항체의 역가가 급격히 증가하기 때문에 환자에게 큰 위 험을 초래할 수 있다. 이러한 이상반응을 초래하 는 항체로는 Rh항체 및 Kidd, Duffy, Kell 항체 등 이 현재까지 알려져 있으며 이로 인해 수혈을 받 은 환자가 사망에 이른 보고가 있다[2].

동종면역반응은 지연성 용혈수혈반응을 일으 킬 뿐만 아니라 더 위험한 결과를 초래하기도 한 다. 영국병원의 $90 \%$ 가 참여한 한 연구에서 6 년 간 보고된 수혈로 인한 오류와 사고 1,630 건을 분 석한 결과, 이 중 188 건(11.5\%)이 지연성 용혈수 혈 이상반응이었으며, 8 건(4.25\%)의 사망사고가 있었는데 직접 사망원인이 수혈이거나 수혈가능 성이 높을 것이라고 분석되었다[4]. 외국에서 이 루어진 Heddle 등의 보고에서도 수혈 후 $2.6 \%$ 에 서 동종면역반응이 발생하였고, 전체 수혈자 중 지연성 용혈수혈반응은 $0.048 \%$ 라고 하였다[4,5]. 2003 2004년 한국에서 입원환자 1,903명을 대상 으로 한 연구에서도 수혈대상자 1903명 중 17명 $(0.89 \%)$ 에서 동종면역반응이 생겼으며, 1 명 $(0.053 \%)$ 에게 지연성 용혈수혈반응이 발생하였다고 보고 하였다[6].

수혈로 인한 동종면역반응은 주로 지속적으로 수혈을 받는 환자에게 발생한다. 국내 한 연구에 서 전체 수혈을 받은 환자 중 적혈구 제제 동종면
역의 빈도는 $0.63 \%$ 였지만, 고형 및 혈액종양질환 등으로 인하여 지속적으로 수혈을 받은 경우 동 종면역의 빈도는 $24.5 \%$ 로 상대적으로 높았다[7]. 이러한 결과를 보았을 때, 장기 수혈환자의 동종 면역 반응을 줄이는 것이 지속적 수혈을 하는데 도움이 될 것이며, 환자 역시 부작용을 경험하는 확률이 줄어들게 되어 질적으로 좋은 수혈을 받 게 된다.

한국인의 흔한 $\mathrm{Rh}$ 표현형은 $\mathrm{CDe}$ 가 약 $40 \%$ 정도 를 차지하고 두 번째로 $\mathrm{CcDEe}$ 표현형이 34 38\% 차지한다고 알려져 있다[7]. 헌혈제제의 $\mathrm{Rh}$ 표현 형도 이와 비슷할 것이므로 특히 $\mathrm{CcDEe}$ 형의 혈 액이 $\mathrm{CDe}$ 환자에게 수혈할 경우 동종면역으로 인 한 Anti-E의 생성이나 Anti-E와 c 등이 동시에 발 생할 수 있으며, 이 후에 $\mathrm{Rh}$ 항원 $\mathrm{E}$ 또는 c가 있는 적혈구 제제 수혈을 다시 받으면 이차성 지연성 용혈수혈이상반응이 발생할 가능성이 커지게 된 다. 따라서, 사전에 Rh C, c, D, E, e형에 대한 면역 표현형 검사를 통해서 환자에게 적합한 적혈구 제제를 찾아서 수혈할 경우, 동종면역반응을 감 소시킬 수 있으며, 더 나아가서 위와 같은 경우에 발생할 수 있는 지연성 용혈수혈 이상반응도 감 소시킬 수가 있다. 이는 미리 면역표현형 검사를 할 경우 기억반응을 야기할 수 있는 해당 항원이 없는 혈액제제를 사용할 수 있기 때문이다.

하지만 만약 환자의 $\mathrm{Rh}$ 표현형과 일치하지 않 은 혈액제제를 수혈할 경우 다음과 같은 2 가지 문제가 발생할 수 있다. 첫 번째로, 동종면역으로 인해 항체를 획득한 경우, 응급 또는 지속적으로 수혈 받는 사람에게는 수혈제제를 적절한 시간에 공급하기가 어려워진다. 적합한 혈액제제를 찾기 위해 많은 수의 제제에 대해 교차시험을 해야 하 므로 시간과 비용 역시 많이 소모된다. 현재 동종 면역반응에서 가장 많은 빈도를 보이는 $\mathrm{Rh}$ 계열 항체가 확인되거나 의심되는 환자의 경우 다음과 
같은 절차를 통해서 적합혈액을 찾는다. 먼저 혈 액은행에서 보관된 혈액 중에서 $\mathrm{Rh}$ 표현형을 검 색하고 해당 항원이 없는 혈액을 선별한다. 그리 고 선별된 혈액제제를 겔카드 교차시험을 실시하 고 교차시험에서 이상이 없는 경우 적합 혈액제 제의 $\mathrm{Rh}$ 항원 검사를 실시하기도 한다. 최종적으 로 항원이 음성인 경우 해당 혈액제제를 출고 할 수 있으며 여기에 소모되는 시간은 약 40 60분 정도가 소모된다. 하지만 환자에게 미리 $\mathrm{Rh}$ 표현 형을 확인하여 동종면역반응을 예방한다면, 혈액 출고시 일반적인 방법의 생리식염수법으로 하는 교차시험으로 5 분만에 혈액을 출고 할 수 있다.

두 번째는 수혈 후에 지연성 용혈수혈반응이 발생하고 나서 환자의 $\mathrm{Rh}$ 표현형 검사를 시행할 경우, 수혈된 혈액으로 인해 $\mathrm{Rh}$ 표현형 결과 판독 이 어려울 수 있어 적합한 수혈제제를 찾기가 힘 들어진다는 것이다. 첫 번째 case의 환자의 경우 $\mathrm{Rh}$ 표현형검사에서 $\mathrm{CcDEe}$ 가 나왔었지만, 실제로 는 C, c, e 항원 양성 혈구와 음성혈구가 공존하는 결과(double cell population)를 보였다. 이런 이유 때문에 혈액원에서는 겔카드 교차시험을 통해서 적합 혈액제제를 출고 하였으며, 검사를 진행하 는데 걸리는 시간은 약 2 시간으로 많은 시간이 소요되었다. 이렇듯이 Rh phenotype이 불확실한 경우 항체가 동정되더라도 겔카드 교차시험을 통 해서 적합 혈액제제를 찾을 수 밖에 없으므로 혈 액원에서는 혈액제제를 출고 하기 전에 검사에 소요되는 시간은 증가 할 수 밖에 없다.

우리나라의 $\mathrm{Rh}-\mathrm{Hr}$ 혈액형 검사 급여 인정기준 은 첫 번째, $\mathrm{Rh}$ 음성인 환자, 두 번째, 신생아 용혈 성 빈혈, 마지막으로 $\mathrm{Rh}-\mathrm{Hr}$ 계열의 비예기항체가 동정되었거나 의심되는 환자이다. 즉 마지막 세 번째의 경우는 이미 동종면역반응으로 감작된 군 에 대해서만 Rh표현형 검사를 할 수 있다. 하지만 캐나다에서 387명의 골수형성이상증후군 (Myelody- splastic syndromes) 환자들을 대상으로 수행한 연 구를 보면, $\mathrm{Rh}$ 와 kell 항원의 표현형 검사를 수혈 전에 예방적으로 하는 것이 이득이 있다고 보고 하였다[8]. 그들은 $\mathrm{MDS}$ 환자와 같이 지속적으로 수혈하는 환자들에게 미리 $\mathrm{Rh}$ 표현형 검사를 하 는 것이 경제적 효과가 있다고 주장하였다. 동종 면역반응이 발생하기 이전에 Rh 와 Kell 항원을 일치시켜 수혈을 하는 경우 드는 비용이 20달러 미만인 경우가 동종면역반응이 발생 한 후에 Rh, Kell 항원을 일치시켜 수혈하는 것보다 비용이 절 감된다는 것이다. 이는 수혈 이후 동종면역 반응 이 나타난 환자에게 추가 검사에 드는 비용보다 손실이 적기 때문이었다. 국내에서도 혈액제제를 공급하는 적십자에서는 $\mathrm{Rh}$ 음성항원을 표시하여 주기 때문에 입고된 혈액제제의 $\mathrm{Rh}$ 표현형검사 를 새로 할 필요가 없고, 항체가 명확히 확인된 경우 출고 시 생리식염수법만으로 검사를 진행하 기 때문에 검사 비용은 20 달러보다 낮은 가격으 로 가능하다. 또한 전체 수혈환자들에게 동종면 역반응이 확인되는 경우보다 지속적으로 수혈 받 는 환자에게서 동종면역반응의 빈도가 높았다 [3,8]. 따라서 국내 수혈공급에 대한 환경적 요인 으로 인해 지속적으로 수혈 받는 환자들에게 예 방적으로 $\mathrm{Rh}$ 표현형 검사를 하는 것은 비용감소 효과가 더 크다고 볼 수 있다[9].

또한 첫 번째 증례를 통해서 혈액 은행에서 불 필요하게 소모된 비용을 계산해 볼 수 있다. $\mathrm{Rh}$ 표현형 검사에서 double cell population이 나와서 추가 수혈 시 19 개의 RBC 혈액 제제를 겔카드 교 차시험 후 적합 제제를 출고 하였다. Liss/coombs 겔카드개 당 가격은 대략 5,217 원이며 4 개를 사 용하여서 20,860 원의 추가 비용이 발생하였다. 또 한 검사에 필요한 인력자원의 소모도 발생했다. 출고 전 혈액제제 1 개의 검사당 5 분 정도 소요되 는 식염수 교차시험과는 달리 19 개의 혈액제재에 
대한 겔카드 교차시험은 약 2 시간이상 소요되었 다. 만약 $\mathrm{Rh}$ 표현형 검사를 사전에 검사하였다면 위에서 언급한 6 개의 농축적혈구 제제는 약 30 분 만에 출고가능하고 4 개의 겔카드에 대한 비용도 지불되지 않았을 것이므로 시간적 경제적 비용을 모두 절감할 수 있었을 것이다. 두 증례에서 보듯 이 수술 이후나 종양환자의 치료 후 지속적으로 수혈이 필요할 때가 있다. 이러한 경우 동종면역 반응으로 감작된 경우에 대해서만 $\mathrm{Rh}$ 표현형 검 사를 하는 것이 아니라 예방적으로 $\mathrm{Rh}$ 표현형 검 사를 하는 것이 경제적으로 효과적이고 적합 혈 액제제를 찾는데 시간적으로도 효율적이라고 볼 수 있다.

\section{요 약}

지연성 용혈수혈 이상반응은 수혈 전 시행하 는 비예기 항체 검사로 예방하기 어려우며 급성 용혈수혈반응과 달리 수혈 수일 후에 발생하므로 임상 의사가 그 원인을 찾기에는 시간이 많이 소 용될 수 있다. 본 저자들은 수혈전 비예기항체 검 사는 음성으로 교차시험상 적합한 혈액을 수혈하 였으나 수혈 후 $\mathrm{Rh}$ 계열에 대한 비예기항체 생성 으로 지연성 용혈수혈반응을 2 예를 경험하였다. 입원 중 수혈 경력이 있던 첫 번째 환자는 퇴원 후 재입원 시 항체동정검사에서 항-E 및 $\mathrm{c}$ 항체가 동정되었다. 암 치료 때문에 만성적인 수혈을 받 았던 두 번째 환자는 수혈 전 검사에서 항체 동정 검사에서 항-C가 확인되었다. 두 환자 모두 비예 기 항체 발생 이후에야 Rh 항원 적합 적혈구제제 를 수혈하였다. 그러나 위의 증례들을 통하여 지 속적으로 수혈 받을 가능성이 있는 환자들은 수 혈 전 통상적인 $\mathrm{Rh}$ 표현형 검사의 필요성을 고려 할 수 있다.

\section{References}

1. Han KS, Park KU, Song EY. Transfusion medicine. 4th ed. Korea Medical Book Publisher, 2014:294-5

2. Kim S, Hur M, Lee KM, Chun W. A case of delayed hemolytic transfusion reaction in a patient with anti-c, anti-E, and anti-Jk(b). Korean J Blood Transfus 2009;20:144-50

3. Kim SM, Kim SH. Analysis of current status of chronic red blood cell transfusion. Korean J Blood Transfus 2016;27:229-36

4. Stainsby D, Williamson L, Jones H, Cohen H. 6 years of shot reporting--its influence on UK blood safety. Transfus Apher Sci 2004;31:123-31

5. Heddle NM, Soutar RL, O'Hoski PL, Singer J, McBride JA, Ali MA, et al. A prospective study to determine the frequency and clinical significance of alloimmunization post-transfusion. Br J Haematol 1995;91:1000-5

6. Park TS, Chang CL, Chung JS, Cho H, Lee EY, Son $\mathrm{HC}$, et al. The frequency and clinical significance of delayed serological transfusion reactions in Korean population. Korean J Blood Transfus 2005;16:20-31

7. Kim JW, Kim WJ. Studies on the RBC alloimmunization after blood transfusions. J Exp Biomed Sci 2006;12:35-42

8. Lin Y, Saskin A, Wells RA, Lenis M, Mamedov A, Callum J, et al. Prophylactic RhCE and Kell antigen matching: impact on alloimmunization in transfusion-dependent patients with myelodysplastic syndromes. Vox Sang 2017;112:79-86

9. Kacker S, Ness PM, Savage WJ, Frick KD, Shirey RS, King KE, et al. Cost-effectiveness of prospective red blood cell antigen matching to prevent alloimmunization among sickle cell patients. Transfusion 2014;54:86-97 